\title{
Perturbation of polyamine metabolism and its relation to cell death in human colon cancer cells treated by 7ß-hydroxycholesterol and 7ß-hydroxysitosterol
}

\author{
STAMATIKI ROUSSI ${ }^{1}$, FRANCINE GOSSÉ ${ }^{1}$, DALAL AOUDÉ-WERNER $^{2}$, XIN ZHANG $^{3}$, \\ PHILIPPE GEOFFROY ${ }^{4}$, MICHEL MIESCH ${ }^{4}$, ERIC MARCHIONI ${ }^{3}$ and FRANCIS RAUL ${ }^{1}$
}

\begin{abstract}
${ }^{1}$ INSERM U682, Université Louis-Pasteur EA3430, Faculté of Médecine, Laboratoire de Prévention Nutritionnelle du Cancer, IRCAD, 1 place de l'hôpital, 67092 Strasbourg; ${ }^{2}$ Aérial, Rue Laurent Fries, Parc d'Innovation, 67412 Illkirch;

${ }^{3}$ Université Louis Pasteur (UMR 7512), Faculté de Pharmacie, Laboratoire de Chimie Analytique et Sciences de l'Aliment, 74 route du Rhin, 67400 Illkirch; ${ }^{4}$ Université Louis Pasteur (UMR 7123), Laboratoire de Chimie Organique Synthétique, 1 rue Blaise Pascal, 67008 Strasbourg, France
\end{abstract}

Received June 16, 2006; Accepted July 28, 2006

\begin{abstract}
OHsitosterol and 7ß-OHcholesterol are natural compounds of plant and animal cells with high structural similarity. Recently it was reported that both compounds induced apoptosis on human colon cancer cells by targeting different signalling pathways. Our study aimed at comparing their effects on polyamine metabolism and its relation to apoptosis. When human colon cancer cells were exposed to $7 ß-O H s i t o s t e r o l$ and to $7 ß-O H c h o l e s t e r o l$ at concentrations inhibiting growth by the same degree, both compounds caused a reduction of polyamine biosynthetic enzyme activity, of the polyamine pools, and an increase of $\mathrm{N}^{1}$-acetylspermidine concentration indicating the enhancement of polyamine catabolism. Exogenous putrescine did not prevent cell death caused

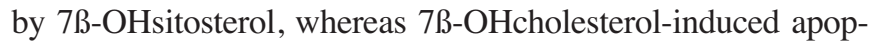
tosis was inhibited. MDL 72527, an inhibitor of polyamine oxidase, an enzyme of the polyamine catabolic pathway, potentiated the antiproliferative effects of 7ß-OHcholesterol by increasing the $\mathrm{N}^{1}$-acetylspermidine pool and enhanced the accumulation of apoptotic cells. In contrast, MDL $72527 \mathrm{did}$ not change the apoptosis rate and the $\mathrm{N}^{1}$-acetylspermidine content in cells treated with $7 ß-\mathrm{OH}$ sitosterol. These data indicate that polyamine metabolic perturbations triggered by $7 ß-\mathrm{OH}$ cholesterol but not by $7 ß-\mathrm{OH}$ sitosterol are related to cell death.
\end{abstract}

Correspondence to: Dr Francis Raul, IRCAD, 1 Place de l'Hôpital, 67091 Strasbourg, France

E-mail: francis.raul@ircad.u-strasbg.fr

Key words: colorectal cancer, apoptosis, hydroxysitosterol, hydroxycholesterol, polyamines, ornithine decarboxylase, MDL 72527

\section{Introduction}

Phytosterols are only present in plants, fruits and vegetables. Among the phytosterols, sitosterol, campesterol and stigmasterol are the most abundant (1). The cholesterol lowering effect of phytosterols is well documented and numerous studies on atherogenenesis have focused on their potential to reduce cholesterol absorption in the small intestine and cholesterol uptake by LDL (2). As for cholesterol, plant sterols undergo oxidation during storage and cooking. The 7ß-hydroxy form of phytosterols and cholesterol is abundant and has also been detected in human serum $(3,4)$. Several studies have reported on the cytotoxic effects of 7ß-hydroxycholesterol (7ß-OHchol) on cancer cells $(3,5)$, but few data exist on the anti-cancer properties of $7 ß$-hydroxysitosterol ( $7 ß-\mathrm{OH}$ sito) $(6,7)$. The difference between these molecules is the presence of an ethyl group on 24' 7ß-OHsito (Fig. 1). Their structural similarities have led to the assumption that a functional similarity exists between 7ß-OHsito and 7ß-OHchol.

We have previously shown that $73-\mathrm{OH}$ sito and $7 \mathrm{~B}-\mathrm{OH}$ chol cause apoptosis on human colonic cancer cells (Caco-2). However, in spite of their structural similarities the two compounds targeted different cell death pathways (8). To gain more insight into the mechanisms involved in their apoptotic effects we studied the impact of the two hydroxysterols on intracellular pathways related to apoptosis and on polyamine metabolism in Caco-2 cells which is up-regulated in this cell line (9).

The natural polyamines are multifunctional constituents of all eucaryotic cells. They are involved in cell proliferation and the maintenance of cell viability. A characteristic of polyamine metabolism is its sophisticated regulation and its perturbation may induce dysfunction and cell death. Growth factors, hormones and polyamines themselves regulate key biosynthetic enzymes such as ornithine decarboxylase and S-adenosylmethionine decarboxylase, and catabolic enzymes such as spermine/spermidine $\mathrm{N}^{1}$-acetyltransferase and polyamine oxidase as well as their uptake and release (10). 

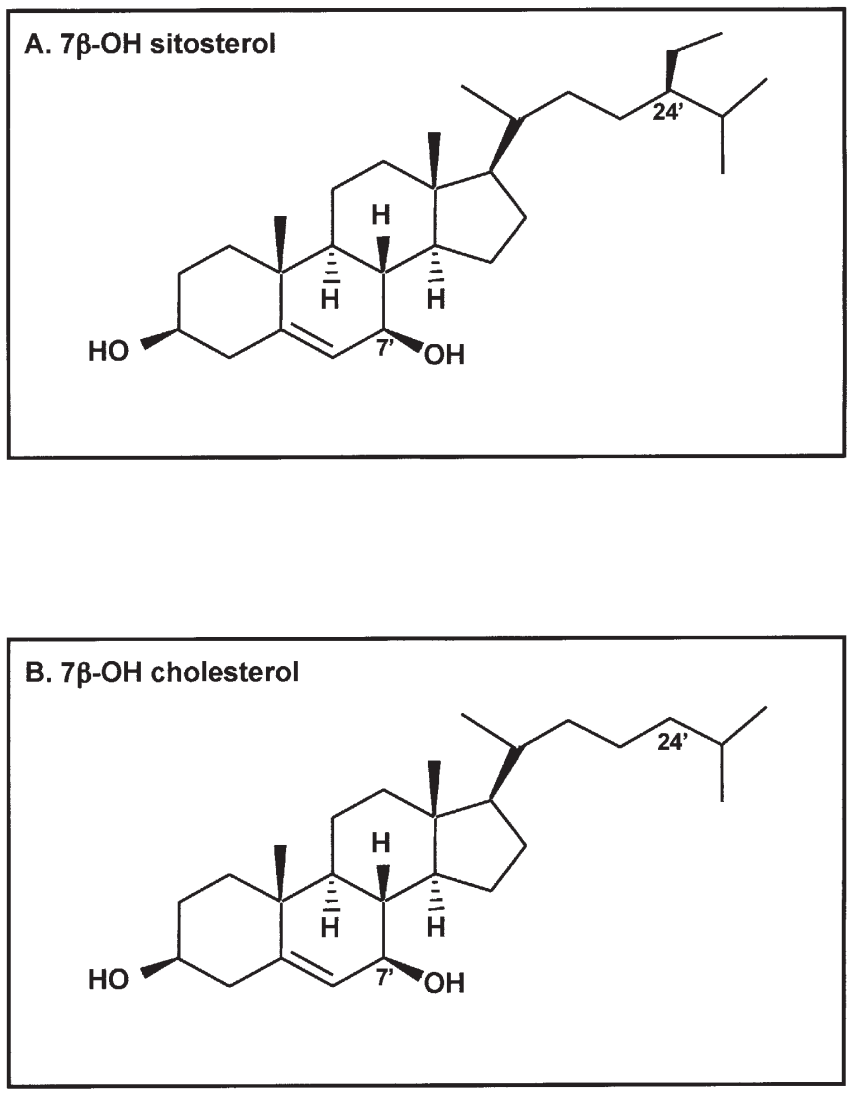

Figure 1. Structure of 7ß-OH sitosterol (A) and 7ß-OH cholesterol (B).

Recently, much attention has focused on the relationship between polyamine metabolism and programmed cell death with many contradictory results. In some cases apoptosis was activated due to the selective depletion of intracellular polyamine pools by using selective inactivators of key enzymes (11). Polyamine depletion has also been achieved by using structural analogues which mimic polyamines in regulatory pathways (12). In return, few data of apoptosis activation during increase of polyamine concentration have been described (13). There is no doubt about the link between the natural polyamines and several intracellular pathways controlling apoptosis and many schemes and hypotheses have been elaborated $(10,14)$.

Our objectives were to compare the effects of $7 ß-\mathrm{OH}$ sito and $73-\mathrm{OHchol}$ on polyamine metabolism in the human colon cancer Caco-2 cells and their relationship to cell death.

\section{Materials and methods}

Reagents. 7ß-OHsito and 7ß-OHchol were obtained from oxidation of the $\beta$-sitosterol and cholesterol respectively. B-sitosterol was purified by preparative adsorption chromatography starting from a commercial mixture of phytosterols (unsaponifiable fraction of Soya oil). The purity of the Bsitosterol was $>95 \%$. The impurities consisted of traces of campesterol. Cholesterol was a Sigma-Aldrich product (SigmaAldrich, Steinheim, Germany). B-sitosterol and cholesterol were oxidized as described previously (15). After purification on silica gel column, 7ß-OHsito and 7ß-OHchol were obtained at approximately $95 \%$ purity. Hydroxysterols were dissolved with ethanol $100 \%$ and for the control group the ethanol did not exceed $0.5 \%(\mathrm{v} / \mathrm{v})$ in the culture medium. MDL 72527 [ $\mathrm{N}^{1}, \mathrm{~N}^{4}$-bis(2,3-butadienyl)-1,4-butanediamine dihydrochloride] was synthesized as described previously (16). Putrescine was purchased from Sigma-Aldrich. $\mathrm{N}^{1}$-acetylspermidine was synthesized as described previously (17).

Cell culture. Human colon adenocarcinoma cells (Caco-2) were obtained from the European Collection of Animal Cell Culture (ECACC, Salisbury, UK). They were cultured in $75-\mathrm{cm}^{2}$ Falkon flasks in Dulbecco's modified Eagle's medium containing $25 \mathrm{mM}$ glucose (DMEM) and supplemented with $10 \%$ heat-inactivated horse serum, $100 \mathrm{U} / \mathrm{ml}$ penicillin, $100 \mu \mathrm{g} /$ $\mathrm{ml}$ streptomycin, $1 \%$ non-essential aminoacids (Gibco, Invitrogen Corp., Cergy Pontoise, France). The use of horse serum avoids oxidative deamination of spermidine and spermine by serum amine oxidase. Cells were incubated at $37^{\circ} \mathrm{C}$ in a humidified atmosphere with $5 \% \mathrm{CO}_{2}$ and subcultured after trypsinization ( $0.5 \%$ trypsin/2.6 mM EDTA). For all experiments, cells were seeded at $0.6-1 \times 10^{6}$ cells in culture dishes (10-cm diameter) or at 4500 cells in 96 -well plates. They were cultured in DMEM supplemented with $3 \%$ heatinactivated horse serum, $5 \mu \mathrm{g} / \mathrm{ml}$ transferrin, $5 \mathrm{ng} / \mathrm{ml}$ selenium and $10 \mu \mathrm{g} / \mathrm{ml}$ insulin (Gibco).

ODC and AdoMetDC assays. Cells (0.6×10\%/plate) were seeded and exposed to different compounds (60 $\mu \mathrm{M} 7 ß-$ OHsito and $30 \mu \mathrm{M} 73-\mathrm{OHchol}) 24 \mathrm{~h}$ after seeding and further incubated for different times. At each time point, cells were harvested by scraping, washed twice in PBS and stored at $-80^{\circ} \mathrm{C}$ until analyses were carried out. Cells were homogenized by sonication in $100 \mathrm{mM}$ Tris- $\mathrm{HCl}$ buffer, $\mathrm{pH} 7.4$ containing $1 \mathrm{mM}$ EDTA, $1 \mathrm{mM}$ dithiothreitol, $0.5 \mu \mathrm{M}$ leupeptin and $0.5 \mathrm{mM}$ phenylmethylsulfonyl fluoride. After centrifugation at $33,000 \mathrm{x} \mathrm{g}$ for $25 \mathrm{~min}$ at $4^{\circ} \mathrm{C}$, ODC and AdoMetDC assays were performed in the supernatants. ODC activity was measured by the rate of ${ }^{14} \mathrm{CO}_{2}$ formation from $\left[1-{ }^{14} \mathrm{C}\right]$ L-ornithine ( $55 \mathrm{mCi} / \mathrm{mmol}$, Amersham Biosciences, France) and AdoMetDC activity by measuring the rate of ${ }^{14} \mathrm{CO}_{2}$ formed from $\left[1-{ }^{14} \mathrm{C}\right] \mathrm{S}$-adenosylmethionine $(60 \mathrm{mCi} / \mathrm{mmol}$, Amersham Biosciences) (18). Results were expressed as $\mathrm{pmol} / \mathrm{h} / \mathrm{mg}$ protein.

Determination of polyamine concentration. Cells $\left(0.6 \times 10^{6} \%\right.$ plate) were seeded and $24 \mathrm{~h}$ later they were incubated in the presence or absence of $60 \mu \mathrm{M} 73-\mathrm{OH}$ sito, $30 \mu \mathrm{M} 73-\mathrm{OHchol}$, $50 \mu \mathrm{M}$ MDL 72527 and combinations of MDL/hydroxysterols for different time points. Cells were collected as described above. The cell pellets were homogenized by sonication in perchloric acid $(200 \mathrm{mM})$, and centrifuged at $3000 \mathrm{x} \mathrm{g}$ for 10 min after standing for $16 \mathrm{~h}$ at $2^{\circ} \mathrm{C}$. The acid-insoluble pellets were used for protein determination and the clear supernatants for the determination of putrescine, spermidine, spermine and $\mathrm{N}^{1}$-acetyl spermidine by separation of the ion pairs formed with $n$-octanesulfonic acid, reaction of the column effluent with $o$-phthalaldehyde/2-mercaptoethanol reagent. The primary amino groups form fluorescent 1-alkylthio-2-alkylisoindole derivatives, which were determined by continuous monitoring of fluorescence intensity (19). Results were expressed as pmol/ mg protein. 

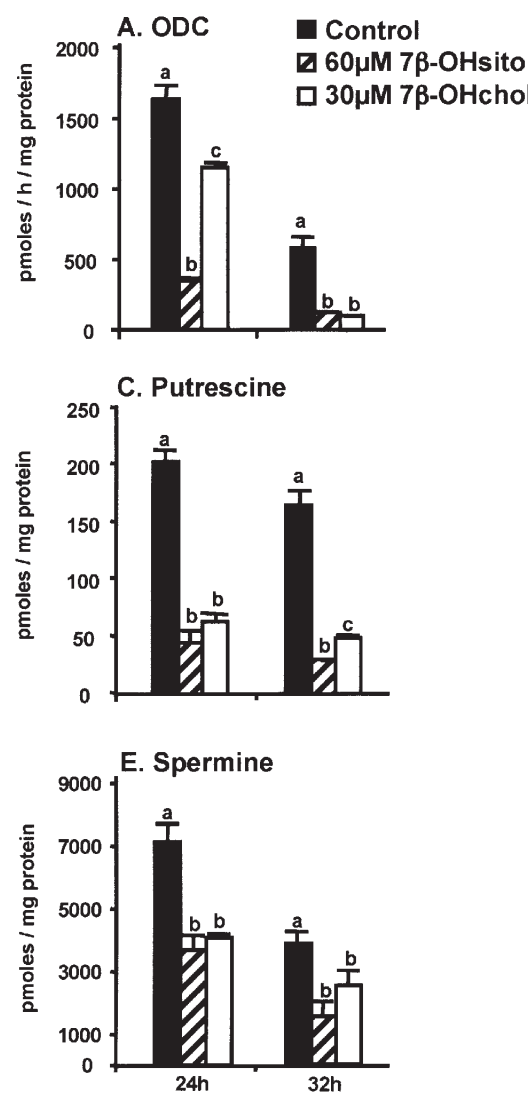

Figure 2. Effects of 7ß-OH sitosterol (7ß-OHsito) and 7ß-OH cholesterol (7ß-OHchol) on ornithine decarboxylase (ODC) and S-adenosyl methionine decarboxylase (AdoMetDC) activity and on intracellular polyamine concentration. Cells were grown in $0.5 \%$ ethanol (control)-containing DMEM, $60 \mu \mathrm{M} 7 ß-\mathrm{OH}$ sito and $30 \mu \mathrm{M} 7 \mathrm{~B}-\mathrm{OH}$ chol for 24 and $32 \mathrm{~h}$. A and B, ODC and AdoMetDc activity (pmol $\mathrm{CO}_{2} / \mathrm{h} / \mathrm{mg}$ protein); $\mathrm{C}$, putrescine; D, spermidine; E, spermine; F, $\mathrm{N}^{1}$-acetylspermidine (pmol/mg protein) in the absence (control) and in the presence of $7 ß-\mathrm{OH}$ sito and $7 \mathrm{~B}-\mathrm{OH}$ chol. Data are the mean \pm SE of at least 3 separate experiments. Statistical differences: $\mathrm{a} \neq \mathrm{b} \neq \mathrm{c}, \mathrm{p}<0.05$.

Effect of putrescine on Caco-2 cell growth. Cells (4500/well) were seeded in 96-well plates and exposed to hydroxysterols. Twenty-four hours after hydroxysterol treatment, $2 \mathrm{mM}$ putrescine (Sigma-Aldrich) was added to the culture medium. Culture medium was changed every $48 \mathrm{~h}$ and fresh solutions of hydroxysterols and putrescine were prepared. Cell culture was stopped at different time points by the addition of $50 \mu 1$ trichloroacetic acid $(50 \%, \mathrm{v} / \mathrm{v})$ and proteins were stained with $100 \mu 1$ sulforhodamine B diluted in $1 \%$ acetic acid $(0.4 \%$, $\mathrm{w} / \mathrm{v})$. Cells were rinsed 3 times with $1 \%$ acetic acid and $200 \mu \mathrm{l} /$ well of $10 \mathrm{mM}$ Tris- $\mathrm{HCl}$ (pH 10.5) was added. Absorbance was measured at $490 \mathrm{~nm}$ (20). The relationship between cell number (protein content/well) and absorbance is linear from 0 to 200,000 cells/well.

Flow cytometry. Cells ( $1 \times 10^{6} /$ plate) were exposed to different compounds $24 \mathrm{~h}$ after seeding and incubated for different time periods. Cell cycle distribution and percentage of hypodiploid DNA cells were analysed by labelling cells with propidium iodide and assays were carried out by flow cytometry (21). After incubation in the dark at $37^{\circ} \mathrm{C}$ for $30 \mathrm{~min}$, the fluorescence of 10,000 cells was analysed using a FACScan flow

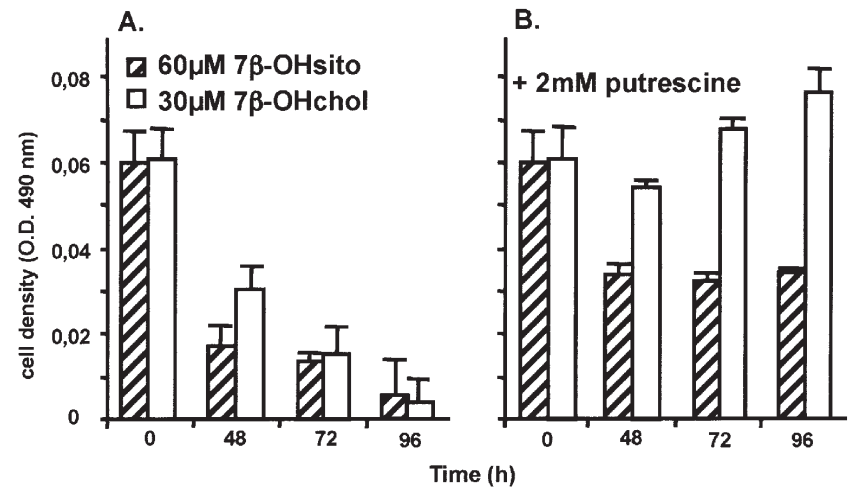

Figure 3. Effect of exogenous putrescine on Caco-2 cell growth after $7 \mathrm{~B}-\mathrm{OH}$ sitosterol (7ß-OHsito) and 7ß-OH cholesterol (7ß-OHchol) treatment. A, cells were treated with $60 \mu \mathrm{M} 7 ß-\mathrm{OH}$ sito and $30 \mu \mathrm{M} 7 ß-\mathrm{OH}$ chol for 48, 72 and $96 \mathrm{~h}$. B, $24 \mathrm{~h}$ after hydroxysterol treatment, $2 \mathrm{mM}$ of putrescine was added. Columns represent cell growth at different time points. Data are presented as the mean \pm SE of at least 3 separate experiments.

cytometer and CellQuest software (Becton Dickinson, San Jose, CA, USA).

Statistical analysis. All experiments were performed at least 3 times. Data are reported as mean \pm SE. Statistical differences between groups were evaluated by one-way ANOVA and specific differences were identified using the Student-NeumanKeuls multiple comparison test or the Student's t-test.

\section{Results}

Alterations of polyamine metabolism by $7 \beta$-OHsito and $7 \beta$ OHchol. Cells were exposed to $60 \mu \mathrm{M} 7 \mathrm{~B}-\mathrm{OH}$ sito and to $30 \mu \mathrm{M} 7 \mathrm{~B}-\mathrm{OH}$ chol for 24 and $32 \mathrm{~h}$. Both compounds inhibited similar cell growth (8). As shown in Fig. $2 \mathrm{~A}$ an $\sim 70 \%$ reduction of ODC activity was observed in cells treated for $24 \mathrm{~h}$ with $7 ß-O H$ sito whereas only a $30 \%$ reduction of enzyme activity was obtained with $7 ß-\mathrm{OHchol}$. At $32 \mathrm{~h}$ both compounds reduced ODC activity similarly (Fig. 2A). In contrast, only $7 ß-\mathrm{OH}$ sito treatment led to a significant $(45 \%)$ decrease of AdoMetDC activity (Fig. 2B).

As shown in Fig. 2C and E, cells exposed to both hydroxysterols exhibited a depletion of the polyamine pool, compared to untreated controls. Putrescine was reduced by $70 \%$, and spermidine and spermine by $40-45 \%$. This was accompanied by a significant increase in the intracellular content of $\mathrm{N}^{1}$ acetylspermidine (Fig. 2F), an indicator of enhanced polyamine catabolism. $\mathrm{N}^{1}$-acetylspermidine was not detected in untreated Caco-2 cells.

Effect of exogenous putrescine on cell growth and death. Putrescine was added to the culture medium $24 \mathrm{~h}$ after starting treatment with the hydroxysterols and it was again added together with the hydroxysterols at each media change. As represented in Fig. 3, inhibition of cell growth observed with $7 ß-O H c h o l$ was prevented with $2 \mathrm{mM}$ putrescine. In cells exposed to $7 ß-\mathrm{OH}$ sito the effect of putrescine was less important.

Flow cytometry analysis of hypodiploid cells was used in order to assess the effect of exogenous putrescine on cell 


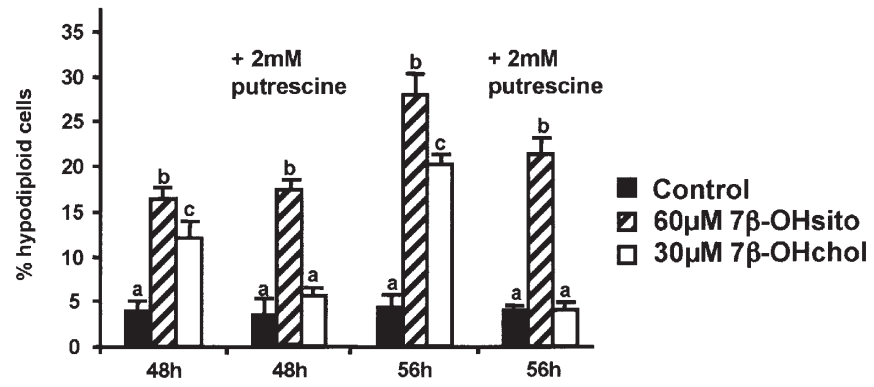

Figure 4. Determination of hypodiploid cells after addition of exogenous putrescine to $7 ß-\mathrm{OH}$ sitosterol (7ß-OHsito) and 7ß-OH cholesterol (7ßOHchol) treated Caco-2 cells. Cells were grown in DMEM in the presence of $0.5 \%$ ethanol, $60 \mu \mathrm{M} 7 ß-\mathrm{OH}$ sito and $30 \mu \mathrm{M} 7 ß-\mathrm{OHchol}$. Exogenous putrescine $(2 \mathrm{mM})$ was added $24 \mathrm{~h}$ after the hydroxysterols. Cells were harvested at 48 and $56 \mathrm{~h}$ after hydroxysterol treatment, stained with propidium iodide and analyzed by flow cytometry. Columns represent the \% of hypodiploid cells. Data are the mean \pm SE of at least 3 separate experiments. Statistical differences: $a \neq b \neq c, p<0.05$.

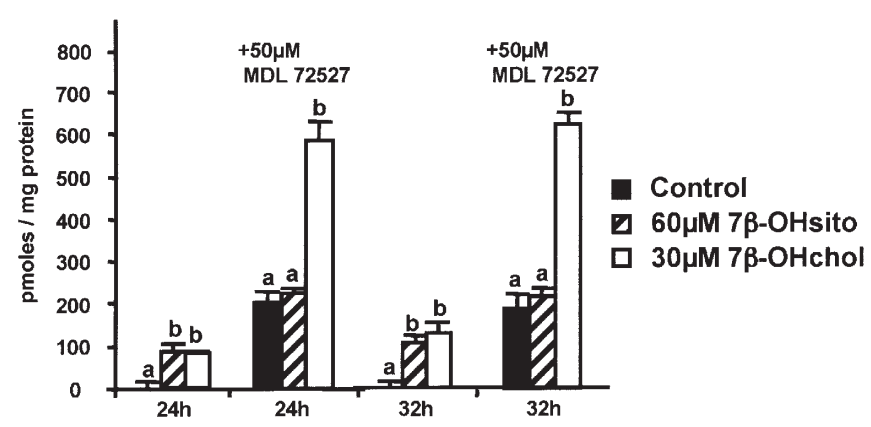

Figure 5. Determination of $\mathrm{N}^{1}$-acetylspermidine in Caco- 2 cells exposed to hydroxysterols and MDL 72527. Caco-2 cells were cultured in DMEM containing $0.5 \%$ ethanol in the absence (control) or presence of $60 \mu \mathrm{M}$ 7ß-OHsito, $30 \mu \mathrm{M} 73-\mathrm{OHchol}$ and $50 \mu \mathrm{M}$ MDL 72527. At 24 and $32 \mathrm{~h}$ cells were isolated and prepared for the determination of $\mathrm{N}^{1}$-acetylspermidine (pmoles/mg protein). All data are the mean \pm SE of at least 3 separate experiments. Statistical differences: $\mathrm{a} \neq \mathrm{b}, \mathrm{p}<0.05$.

death after treatment with hydroxysterols (Fig. 4). Cells were exposed to hydroxysterols for $24 \mathrm{~h}$ and then exogenous putrescine was added to cells. The proportion of hypodiploid cells was determined at 24 and $32 \mathrm{~h}$ after putrescine addition. These time periods corresponded to 48 and $56 \mathrm{~h}$ of culture in the presence of the hydroxysterols. In the absence of putrescine the amount of hypodiploid cells was significantly increased by hydroxysterol treatments compared to controls. In the presence of putrescine the number of hypodiploid cells was significantly reduced in $7 \mathrm{~B}-\mathrm{OH}$ chol-treated cells as compared to cells exposed to $7 ß-\mathrm{OH}$ sito. These data are in accordance with data shown in Fig. 3B where cell growth was inhibited by exogenous putrescine in the case of $7 ß-$ OHchol.

Effect of MDL 72527 and $N^{1}$-acetylspermidine on hydroxysterol-mediated cell death. As shown in Fig. 5, $\mathrm{N}^{1}$ acetylspermidine accumulated in cells in the presence of the PAO inhibitor (50 $\mu \mathrm{M}$ MDL 72527). A 3-fold increase of $\mathrm{N}^{1}$-acetylspermidine was observed in cells treated with 73 OHchol and MDL 72527, whereas no changes were observed

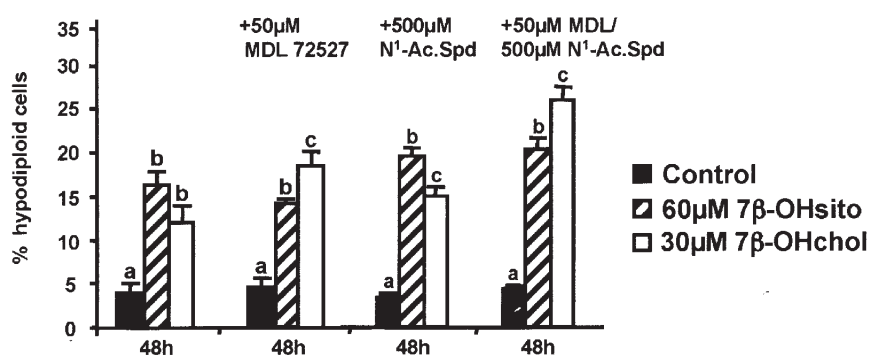

Figure 6. Effect of hydroxysterols, MDL 72527 and $\mathrm{N}^{1}$-acetylspermidine on hypodiploid cell formation. Caco- 2 cells were treated with DMEM containing $0.5 \%$ ethanol (control), $60 \mu \mathrm{M} 73-\mathrm{OH}$ sito and $30 \mu \mathrm{M} 73-\mathrm{OH} c h o l$ in the absence or presence of $50 \mu \mathrm{M}$ MDL $72527,500 \mu \mathrm{M} \mathrm{N}^{1}$-acetyl spermidine (N1-AcSpd) and MDL/N ${ }^{1}-A c S p d$. Cells were harvested at $48 \mathrm{~h}$, stained with propidium iodide and hypodiploid cells were determined by flow cytometry. Columns represent the $\%$ of hypodiploid population. Data are the mean \pm SE of at least 3 separate experiments. Statistical differences: $a \neq b \neq c, p<0.05$.

in cells exposed to a combination of $73-\mathrm{OH}$ sito and MDL 72527 .

The number of apoptotic cells was significantly increased after a combined treatment with 7ß-OHchol/MDL72527 when compared to cells exposed to $7 ß-\mathrm{OH}$ sito in the presence or absence of MDL 72527 (Fig. 6). These data suggest that the accumulation of $\mathrm{N}^{1}$-acetylspermidine caused by MDL 72527 is correlated to the apoptotic effect of $7 ß-\mathrm{OHchol}$. Moreover, when cells were exposed to $500 \mu \mathrm{M}$ of exogenous $\mathrm{N}^{1}$-acetylspermidine the amount of apoptotic cells was further enhanced when the acetylated polyamine was associated with MDL 72527 but only in the presence of $7 \mathrm{~B}-\mathrm{OHchol}$ and not in the presence of 7ß-OHsito (Fig. 6).

\section{Discussion}

We have previously reported that $7 ß-\mathrm{OH}$ sito at $60 \mu \mathrm{M}$ and $7 ß-O H c h o l$ at $30 \mu \mathrm{M}$ similarly inhibited Caco-2 cell growth and induced apoptosis as it was demonstrated by DNA fragmentation and caspase-9 activation (8). This study demonstrates that both compounds impair polyamine biosynthesis; 7ßOHsito was more potent than $7 \mathrm{~B}-\mathrm{OH}$ chol by inhibiting the activity of both polyamine biosynthetic enzymes, ODC and AdoMetDC. A high expression of ODC and AdoMetDC is characteristic of cancer cells (22). Polyamine metabolism is a target in colon cancer chemoprevention and an increase of polyamine catabolism is usually associated with a decrease of polyamine concentration (9).

The decrease in the activity of polyamine biosynthetic enzymes and in the intracellular polyamine content seem not to be directly related to apoptosis induced by $7 ß-\mathrm{OH}$ sito since cell growth inhibition was not prevented by exogenous putrescine. In contrast, we found that $7 ß-\mathrm{OHchol}$-mediated apoptosis was significantly reduced by putrescine. This suggests that in 73 -OHchol-mediated apoptosis, the perturbation of polyamine metabolism plays a more important role than in $7 \mathrm{~B}-\mathrm{OH}$ sitoinduced apoptosis.

Our data show that both hydroxysterols caused an activation of intracellular polyamine catabolism as indicated by the enhanced accumulation of acetylated polyamines. Two key enzymes are involved in polyamine catabolism: spermine/ 
spermidine acetyl transferase (SSAT) and PAO. Using spermine and spermidine as substrates, SSAT generates the formation of $\mathrm{N}^{1}$-acetyl polyamines which are substrates of PAO (23). Inactivation of PAO by MDL 72527 is followed by a decrease of putrescine and spermidine pools and an increase of acetylated polyamines (24).

We report that, combined with hydroxysterols, MDL 72527 reduced the polyamine content of Caco- 2 cells. However the concentration of $\mathrm{N}^{1}$-acetylspermidine and the number of apoptotic cells were increased when $7 ß-\mathrm{OHchol}$ was associated with MDL 72527. Similar effects were not observed in the presence of 7ß-OHsito. Since MDL 72527 inactivates PAO, the observed increase of $\mathrm{N}^{1}$-acetylspermidine may be caused by the prevention of its degradation. Alternatively, an activation of SSAT cannot be excluded. Furthermore, we found that these effects could be further enhanced by exogenous $\mathrm{N}^{1}$ acetylspermidine, indicating a direct involvement of acetylated polyamines on cell death in the presence of $7 \AA-O H c h o l$. These effects were not observed with 7ß-OHsito.

Depletion of acetyl-CoA due to the massive formation of $\mathrm{N}^{1}$-acetylpolyamines may contribute to growth inhibition $(25,26)$ and one may speculate about the possibility that the accumulation of intracellular $\mathrm{N}$-acetylpolyamines affects histone acetylation by competing with acetylCoA:spermidine $\mathrm{N}^{8}$-acetyltransferase, an enzyme that has also histone acetylating properties (27). However, these and related effects are more likely to be observed in situations of excessive SSAT induction than under the conditions of the present study, although they cannot be excluded at present.

We have previously shown that $7 ß-\mathrm{OH}$ sito and $7 \AA-\mathrm{OHchol}$ induced apoptosis on colon cancer cells by targeting different pathways in spite of their structural similarity (8). In the case of 7ß-OHsito, a caspase-dependent pathway is activated whereas, in the case of $7 \AA-O H c h o l$, the process is more complex and involves various caspase-independent factors. These differences may be related to the alkyl side chain present at position 24' for 7ß-OHsito. Cholesterol oxides are wellknown modulators of cholesterol metabolism which affect cell proliferation and death (3), and may interact with polyamine metabolism. However, it was shown that plant sterols have no effect on cholesterol metabolism due to the presence of the alkyl side chain which prevents any interaction with molecules implicated in cholesterol biosynthesis (28). However, no data exist for plant sterol oxides. It was previously reported that the alkyl side chain renders the molecule more hydrophobic and alters the composition of cell membrane lipids leading to the activation of cell factors and pathways implicated in cell viability and death (29).

The present report indicates that $73-\mathrm{OHchol}$ and $73-\mathrm{OH}$ sito both alter polyamine biosynthesis and catabolism but to a different degree. Moreover, alterations in polyamine metabolism initiated by $73-\mathrm{OHchol}$ have a direct incidence on Caco-2 cell death, a situation which was not observed for 7ß-OHsito.

\section{Acknowledgements}

This work was supported by a grant (RARE 015 No. $02 \mathrm{P}$ 064) from the Ministère de l'Education Nationale et de la Recherche, France), La Ligue Contre Le Cancer, Comité du
Haut-Rhin, France, and the Association pour la Recherche sur le Cancer (ARC), France. The authors are grateful to Dr Nikolaus Seiler for his advice and critical reading of the manuscript.

\section{References}

1. Plat $\mathbf{J}$ and Mensink RP: Plant stanol and sterol esters in the control of blood cholesterol levels: mechanism and safety aspects. Review article. Am J Cardiol 96: 15-22, 2005.

2. Ostlund RE Jr: Phytosterols and cholesterol metabolism. Review article. Curr Opin Lipidol 15: 37-41, 2004.

3. Schroepfer GJ Jr: Oxysterols: modulators of cholesterol metabolism and other processes. Review article. Physiol Rev 80: 361-554, 2000.

4.Plat J, Brzezinka H, Lutjohann D, Mensink RP and Von Bergmann $\mathrm{K}$ : Oxidized plant sterols in human serum and lipid infusions as measured by combined gasliquid chromatography-mass spectrometry. J Lipid Res 42: 2030-2038, 2001.

5. Monier S, Samadi M, Prunet C, Denance M, Laubriet A, Athias A, Berthier A, Steinmetz E, Jurgens G, Negre-Salvayre A, Bessede G, Lemaire-Ewing S, Neel D, Gambert P and Lizard G: Impairment of the cytotoxic and oxidative activities of 7 betahydroxycholesterol and 7-ketocholesterol by esterification with oleate. Biochem Biophys Res Commun 303: 814-824, 2003.

6. Ryan E, Chopra J, McCarthy F, Maguire AR and O'Brien NM: Qualitative and quantitative comparison of the cytotoxic and apoptotic potential of phytostérol oxidation products with their corresponding cholesterol oxidation products. Br J Nutr 94: 443-451, 2005.

7. Maguire L, Konoplyannikov M, Ford A, Maguire AR and O'Brien NM: Comparison of the cytotoxic effects of betasitosterol oxides and a cholesterol oxide, 7beta-hydroxycholesterol, in cultured mammalian cells. Br J Nutr 90: 767-775, 2003.

8. Roussi S, Winter A, Gosse F, Werner D, Zhang X, Marchioni E, Geoffroy P, Miesch M and Raul F: Different apoptotic mechanisms are involved in the antiproliferative effects of 7 betahydroxysitosterol and 7beta-hydroxycholesterol in human colon cancer cells. Cell Death Differ 12: 128-135, 2005.

9. Milovic V and Turchanowa L: Polyamines and colon cancer. Review article. Biochem Soc Trans 31: 381-383, 2003.

10. Gerner EW and Meyskens FL Jr: Polyamines and cancer: old molecules, new understanding. Review article. Nat Rev Cancer 4: 781-792, 2004.

11. Seiler N: Thirty years of polyamine-related approaches to cancer therapy. Retrospect and prospect. Part 2. Structural analogues and derivatives. Review article. Curr Drug Targets 4: 565-585, 2003.

12. Porter CW, Berger FG, Pegg AE, Ganis B and Bergeron RJ: Regulation of ornithine decarboxylase activity by spermidine and the spermidine analogue $\mathrm{N}^{1} \mathrm{~N}^{8}$-bis(ethyl)spermidine. Biochem J 242: 433-440, 1987

13. Poulin R, Pelletier G and Pegg AE: Induction of apoptosis by excessive polyamine accumulation in ornithine decarboxylaseoverproducing L1210 cells. Biochem J 311: 723-727, 1995.

14. Seiler N and Raul F: Polyamines and apoptosis. Review article. J Cell Mol Med 9: 623-642, 2005.

15. Zhang X, Julien-David D, Miesch M, Geoffroy P, Raul F, Roussi S, Aoude-Werner D and Marchioni E: Identification and quantitative analysis of betasitosterol oxides in vegetable oils by capillary gas chromatography-mass spectrometry. Steroids 70 : 896-906, 2005.

16. Bey P, Bolkenius FN, Seiler N and Casara P: N-2,3-Butadienyl1,4-butanediamine derivatives: potent irreversible inactivators of mammalian polyamine oxidase. J Med Chem 28: 1-6, 1985.

17. Dredar SA, Blankenship JW, Marchant PE, Manneh V and Fries DS: Design and synthesis of inhibitors of $\mathrm{N}^{8}$-acetyl spermidine deacetylase. J Med Chem 32: 984-989, 1989.

18. Richman RA, Underwood LE, Van Wyk JJ and Voina SJ: Synergistic effect of cortisol and growth hormone on hepatic ornithine decarboxylase activity. Proc Soc Exp Biol Med 138: 880-884, 1971.

19. Seiler N and Knödgen B: High-performance liquid chromatographic procedure for the simultaneous determination of the natural polyamines and their monoacetyl derivatives. J Chromatogr 221: 227-235, 1980. 
20. Skehan P, Storeng R, Scudiero D, Monks A, McMahon J, Vistica D, Warren JT, Bokesch H, Kenney S and Boyd MR: New colorimetric cytotoxicity assay for anticancer-drug screening. J Natl Cancer Inst 82: 1107-1112, 1990.

21. Nicoletti I, Migliorati G, Pagliacci MC, Grignani F and Riccardi C: A rapid and simple method for measuring thymocyte apoptosis by propidium iodide staining and flow cytometry. J Immunol Methods 139: 271-279, 1991.

22. Babbar N and Gerner EW: Polyamines as modifiers of genetic risk factors in human intestinal cancers. Review article. Biochem Soc Trans 31: 388-392, 2003.

23. Bolkenius FN and Seiler N: Acetylderivatives as intermediates in polyamine catabolism. Review article. Int J Biochem 13: 287-292, 1981.

24. Seiler N, Duranton B and Raul F: The polyamine oxidase inactivator MDL 72527. Review article. Prog Drug Res 59: 1-40, 2002.
25. Kee K, Vujcic S, Merali S, Diegelman P, Kisiel N, Powell CT, Kramer DL and Porter CW: Metabolic and antiproliferative consequences of activated polyamine catabolism in LNCaP prostate carcinoma cells. J Biol Chem 279: 27050-27058, 2004.

26. Babbar N, Gerner E and Casero RA Jr: Induction of spermidine/ spermine $\mathrm{N}^{1}$-acetyltransferase (SSAT) by aspirin in Caco-2 colon cancer cells. Biochem J 394: 317-324, 2006.

27. Desiderio MA, Weibel M and Mamont PS: Spermidine nuclear acetylation in rat hepatocytes and in logarithmically growing rat hepatoma cells: comparison with histone acetylation. Exp Cell Res 202: 501-506, 1992.

28. Kakis $\mathrm{G}$ and Kuksis A: Effect of intravenous infusion of Intralipid, cholesterol, and plant sterols on hepatic cholesterogenesis. Can J Biochem Cell Biol 62: 1-10, 1984.

29. Awad AB, Chen YC, Fink CS and Hennessey T: beta-Sitosterol inhibits HT-29 human colon cancer cell growth and alters membrane lipids. Anticancer Res 16: 2797-2804, 1996. 